\title{
Genotype $\times$ environment interaction for morphological and quality traits of wheat varieties under different nitrogen regimes in the foothills of Shivalik range of Himalayas
}

\author{
Meenakshi Uniyal*, J. P. Jaiswal, Birendra Prasad and Rishi Pal Gangwar \\ Department of Genetics and Plant Breeding, G.B. Pant University of Agriculture and Technology, \\ Pantnagar- 263145 (Uttarakhand), INDIA \\ "Corresponding author. E-mail: uniyalmeenakshi53@gmail.com
}

Received: January 22, 2016; Revised received: July 12, 2016; Accepted: October 6, 2016

\begin{abstract}
Variation among twelve winter wheat varieties with respect to $\mathrm{N}$ efficiency (NE) were assessed in field trial planned as per factorial experimental design (two years $\times$ three nitrogen doses $\times$ twelve genotypes) in which treatments were randomized in three replications under three nitrogen levels (control, 150, $250 \mathrm{~kg} / \mathrm{ha}$ ) for two successive years at N. E. Borlaug Crop Research Center, Pantnagar. Stability analysis of nitrogen efficiency contributing traits was performed using mean performance, linear regression and the deviation from regression. No single genotype performed well enough for all the traits under study. QLD 33, HD 2967 and QLD 39 were stable for root length showing good performance for nitrogen uptake. HD 3112 was most stable variety for most of the characters whereas, QLD 33 was found to perform best under higher levels of nitrogen fertilisation, thus, not efficient enough. But, QLD 33 showed delayed maturity which could be linked with an increase in grain yield thus, it could be said that functional stay green phenotypes should increase the grain filling period and boost yield.
\end{abstract}

Keywords: $\mathrm{G} \times \mathrm{E}$ interaction, Morphology, Nitrogen use efficiency, Quality, Wheat genotypes

\section{INTRODUCTION}

The prime objective of a breeder for any crop improvement programme has always been stable grain yield. Its quiet evident from the past researches that in order to improve abiotic stress tolerance, direct selection for yield should be adopted and thereby subjecting the genotypes to stress environments for further research. And one of the major concerns is related to nitrogen use efficiency (NUE). Revolution holding grounds in India, breeding of modern wheat varieties has been mainly done by optimal input management system for cultivation which includes application of high levels of $\mathrm{N}$ (Nitrogen) fertilizer (Hirel et al., 2007). But, with the time this excessive use of nitrogen fertilisers has adversely affected the environment. Wheat plants utilize nearly $30-40 \%$ of the applied $\mathrm{N}$ (Raun et al., 2002) and rest i.e. $>60 \%$ is lost in form of or in combination through denitrification, surface runoff, leaching, etc. With these negative impacts on environment it has necessitated use of less $\mathrm{N}$ fertilizer and selecting plants which must be positively responsive to $\mathrm{N}$ with maintaining good levels of both yield and grain protein content (Witcombe et al., 2008).

In wheat production, nitrogen contributes as a major prerequisite affecting protein content and baking quality thus, ultimately affecting the commercial value of the produce. According to Moll et al. (1982), grain nitrogen uptake and nitrogen availability to the crop during the growth period are the two components of NUE. Whereas,
Raun et al. (2002) explained NUE to be the N recovered in yield as a proportion of $\mathrm{N}$ applied, allowing for initial soil $\mathrm{N}$ conditions, i.e. $\mathrm{NUE}=(\mathrm{N}$ crop $-\mathrm{N}$ from soil $) /(\mathrm{N}$ fertilizer). Le Gouis et al. (1996) first showed the genetic variability in wheat for efficiency in wheat with respect to nitrogen. In order to improve the wheat quality either of the two ways can be adopted, first, improve the protein quality of the cultivar; second, improve the nitrogen efficiency of the cultivar which would ultimately affect the gain protein content. With this, it has also been observed that for a specific cultivar, its maximum protein and maximum yield are generally not obtained by application of same strategy of fertilization (Lopez-Bellido and Lopez-Bellido, 2001). Thus, differences in climate along with cultivars and also management practices may account here for efficient nitrogen use (Bellidoa et al., 2005). This makes phenotyping an important tool for selecting the traits contributing to NUE by evaluating their performance under different environmental conditions. Ortiz-Monasterio (1997) gave light upon the contribution of root related traits in nitrogen uptake efficiency by reporting that at low soil $\mathrm{N}$ levels there was better expression of uptake while at high $\mathrm{N}$ levels utilization is better expressed. In order to improve NUpE (Nitrogen Uptake Efficiency), optimizing the rooting system will be an important consideration. A recently developed model indicated that the deeper the relative distribution of the roots, the greater the $\mathrm{N}$ capture as a proportion of that available to the plant (King et al., 2003). It has also been 
reported that the efficiency components are inherited in a manner favourable for wheat selection (Gorny et al., 2011). Bogard et al. (2010) stated that plant $\mathrm{N}$ uptake is also interlinked with the senescence of the plant. Some evidence from field experiments suggested that varieties with high post-anthesis $\mathrm{N}$ uptake deviate from the commonly observed negative relationship between grain protein concentration and yield. In such varieties, higher protein concentration is not associated with low yield, as is often the case. This necessitates the study of genotype $\times$ environment interaction (GEI) (Annichiarico, 2002).

GEI helps to develop the ideotypes for specific environment or stable across majority of environments which is again of major concern. GEI can also help in indirect selection to define useful target environments. Therefore, plant breeders include study of response of genotypes by conducting experiments in different environments to figure out $\mathrm{G} \times \mathrm{E}$ interaction. Objectives of our trials were to analyze GEI for different wheat varieties under different nitrogen regimes and to figure out traits affecting the nitrogen efficiency in bread wheat which would finally influence the quality of the produce.

\section{MATERIALS AND METHODS}

Plant material and field trials: The experiment was planned as per factorial experimental design (two years $\times$ three nitrogen doses $\times$ twelve genotypes) in which twelve elite winter wheat varieties (UP 2672, QLD 11, UP 2825, HD 3112, DBW 97, QLD 39, GW 445, HD 3104, HD 2932, QLD 33, HD 2967 and DBW 621-50) treatments were randomized in three replications under three $\mathrm{N}$ (nitrogen) levels each for two successive rabi seasons (2012-13 and 2013-2014) at N. E. Borlaug Crop Research Center, Pantnagar. Different doses applied (split doses) were $0,150,250(\mathrm{~kg} / \mathrm{ha})$ such that we got six environments i.e. $\mathrm{E}_{1}\left(\mathrm{Y}_{1} \mathrm{~N}_{0}\right), \mathrm{E}_{2}\left(\mathrm{Y}_{1} \mathrm{~N}_{150}\right), \mathrm{E}_{3}\left(\mathrm{Y}_{1} \mathrm{~N}_{250}\right), \mathrm{E}_{4}\left(\mathrm{Y}_{2} \mathrm{~N}_{0}\right)$, $\mathrm{E}_{5}\left(\mathrm{Y}_{2} \mathrm{~N}_{150}\right)$ and $\mathrm{E}_{6}\left(\mathrm{Y}_{2} \mathrm{~N}_{250}\right)$.

Geographically, Pantnagar is situated at the latitude of $29^{\circ}$ $\mathrm{N}$ latitude, $79.3^{\circ} \mathrm{E}$ longitude and at an altitude of 243.84 meters above mean sea level. The university falls under the subtropical zone and situated in the tarai region on the foothills of Shivalik range of the Himalayas.

Evaluation and data analysis: The stability parameters were calculated as per the procedure given by Eberhart and Russell (1966) in which three parameters viz., mean $(\mathrm{m})$, regression of individual mean performance on environmental index $\left(b_{i}\right)$, and deviation from regression $(d)$ to categorize the genotypes for their stability used in the form of $\mathrm{Y}_{\mathrm{ij}}=\mathrm{m}+\mathrm{b}_{\mathrm{i}} \mathrm{I}_{\mathrm{j}}+\mathrm{d}_{\mathrm{ij}}$. This model provides a way of partitioning the genotype $\times$ environment interaction of each genotype into two parts, the variation due to the response of the variety in the varying environmental indices, and the unexplained deviation from the regression on the environmental index.

\section{RESULTS AND DISCUSSION}

The analysis of variance for stability using Eberhart

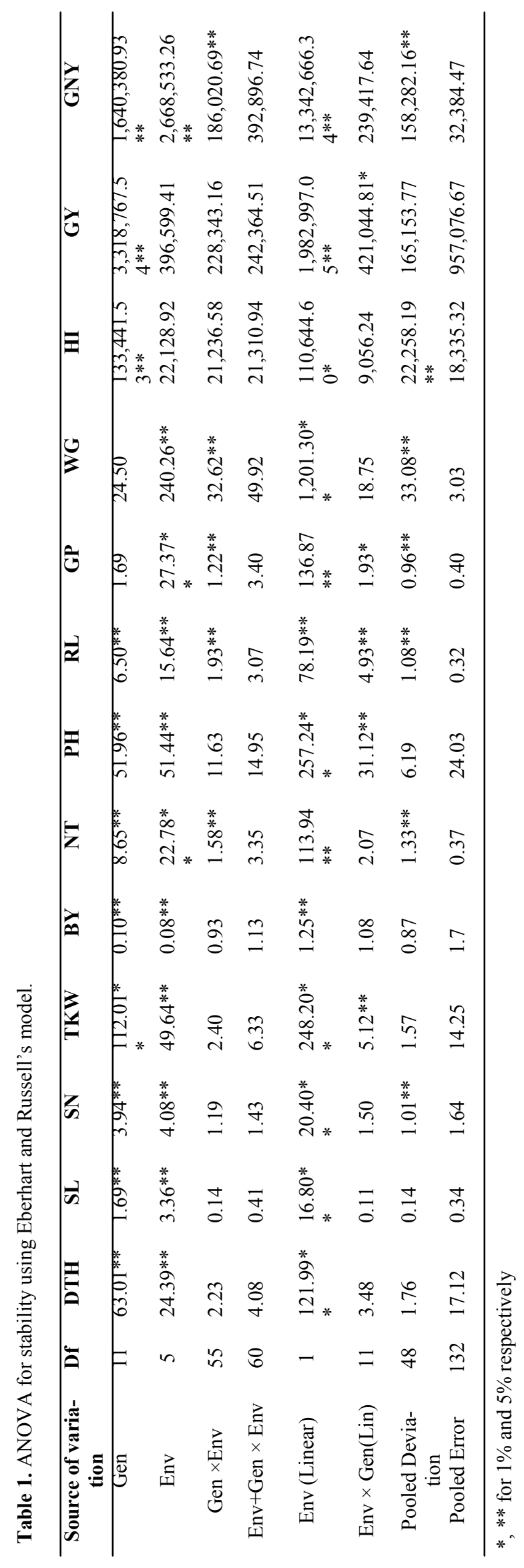


Meenakshi Uniyal et al. / J. Appl. \& Nat. Sci. 8 (4): 1770-1774 (2016)

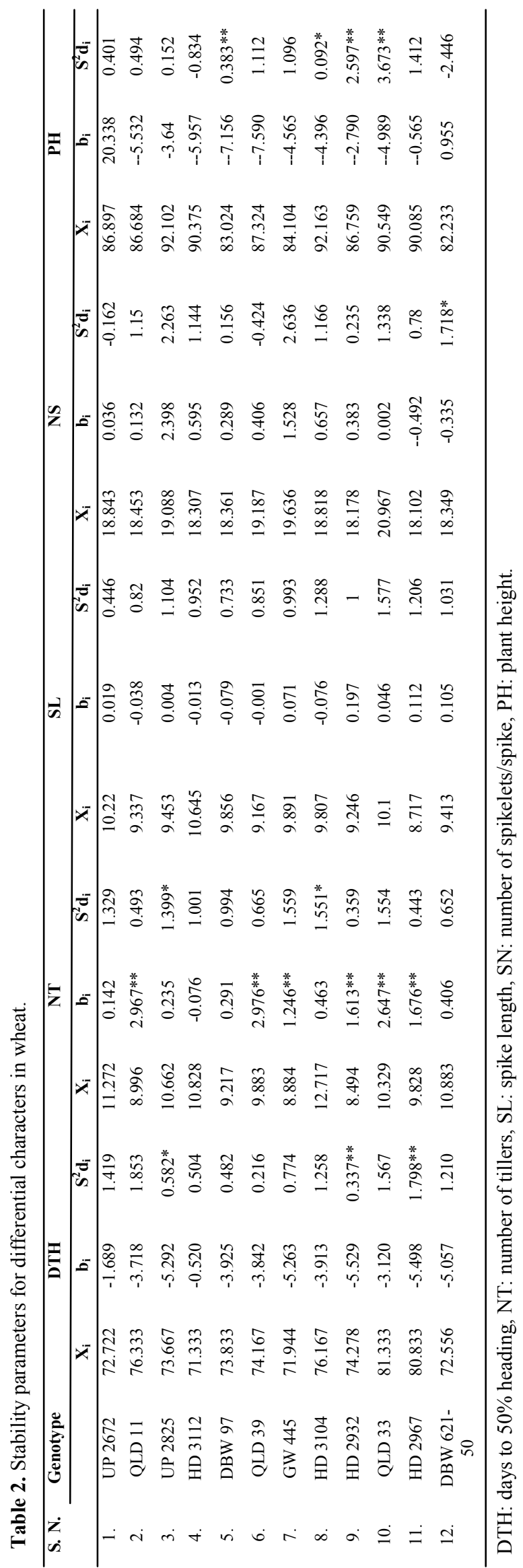

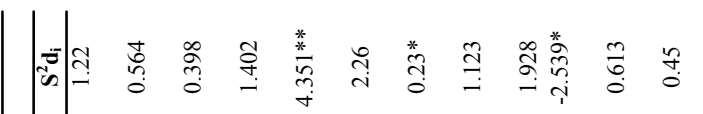

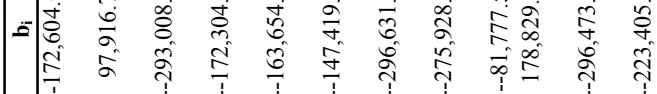

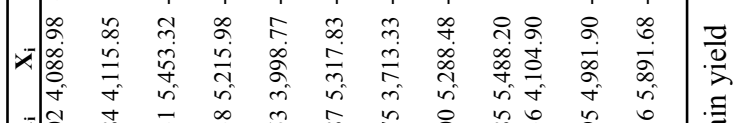
药

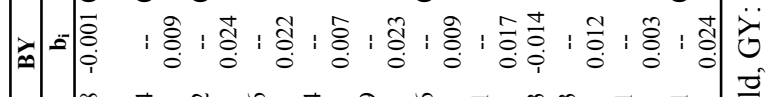

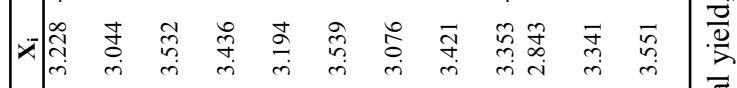

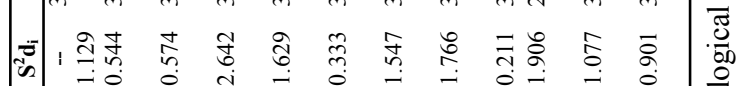

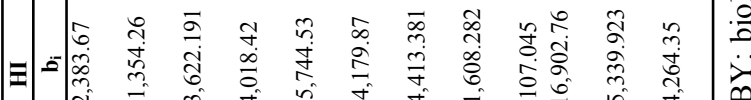

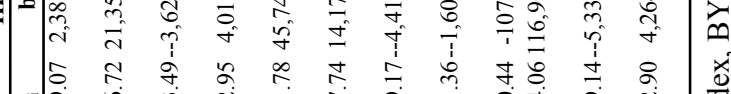

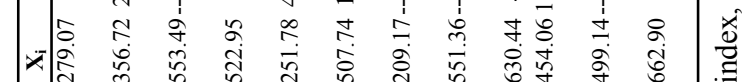

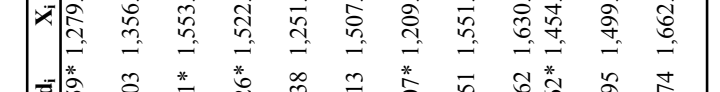

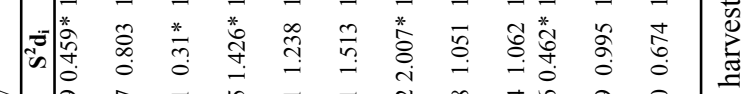

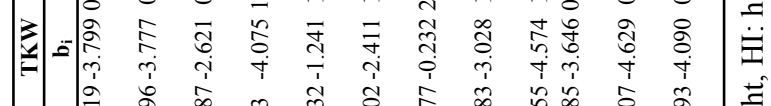

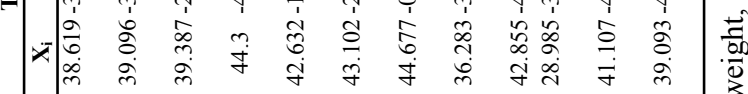

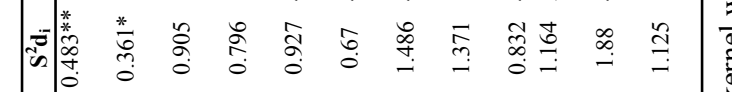

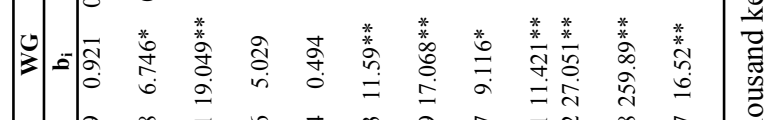

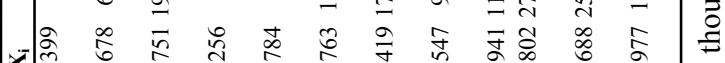

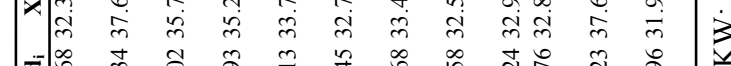

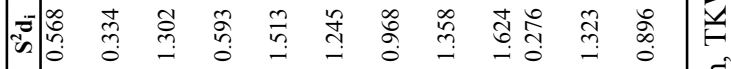

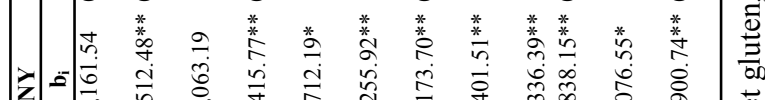

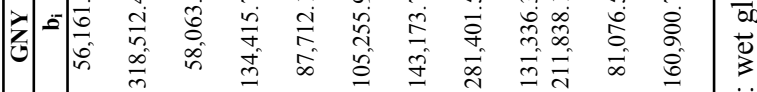

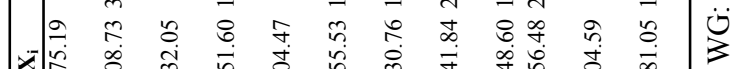

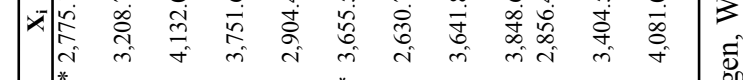

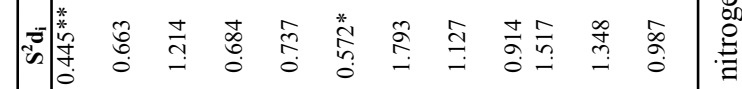

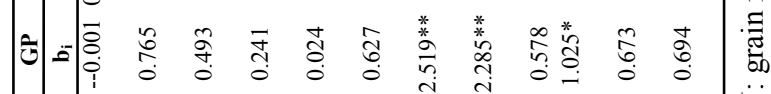

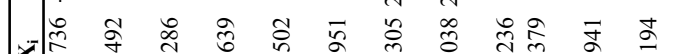

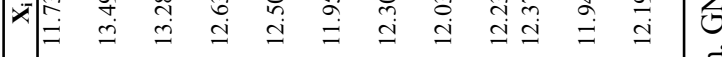

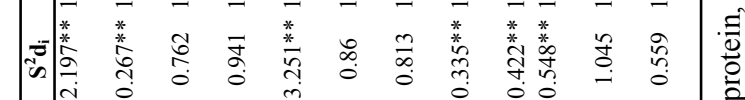

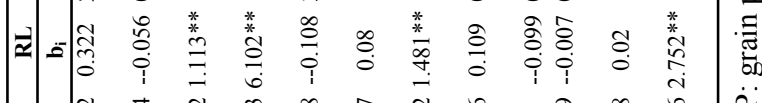

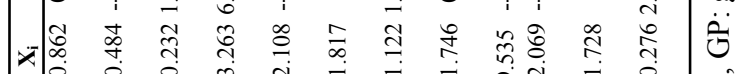

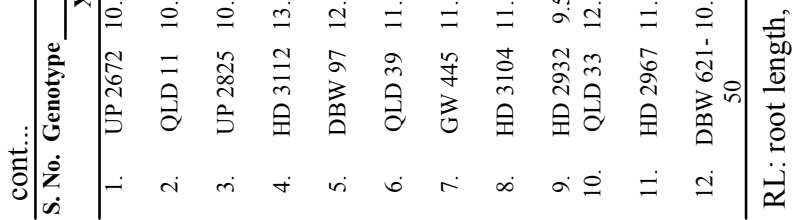


and Russell's model has been depicted in table 1 in which the mean squares due to genotypes was found significant for all traits except wet gluten and grain protein content, whereas for environment all traits showed significant mean sum of squares except for harvest index and grain yield. The mean sum of squares due to $G \times E$ interaction were significant for number of tillers, root length, grain protein, wet gluten and grain nitrogen content of wheat varieties, while for other traits the values of interaction estimate were non-significant.

None of the wheat genotypes had stable performance for all the characters over all six environments as were advocated as been depicted in table 2. QLD 11 showed $b_{i}$ and $S^{2} d_{i}$ values significant which clearly shows this genotype showed varying performance across all environments. For days to 50\% heading, only HD 3112 exhibited stable performance with mean less than the general mean, linear regression coefficient value near unity and negligible deviation from regression. UP 2825, HD 2932 and HD 2967 showed b value significantly different from unity whereas the remaining of the genotypes exhibited non-significant deviation. Significant genotypes indicated their fluctuation in performance for this trait across the environments. Whilst talking about spike length, GW 445, HD 3112, HD 3104 and DBW 97 were recognized as the stable genotypes over all environments because of their higher mean, $b_{i} \approx 1$ and $S^{2} d_{i} \approx 0$ across the environments. QLD 33 showed specific adaptability for rich environment due to its higher mean, linear regression coefficient value higher than unity and high deviation from regression. Jena et al. (2005) in his experiment revealed that both linear and non-linear components were predominant in plant height, spike length and number of grains per spike, whereas non-linear components were observed in all characters except spike length. For plant height there most desirable and stable genotype was HD 2967 due to high mean (>88.22), $\mathrm{b}_{\mathrm{i}} \approx 1$ and $\mathrm{S}^{2} \mathrm{~d}_{\mathrm{i}} \approx 0$ exhibiting higher plant height. QLD 33, HD 2967 and QLD 39 were considered to be stable for root length, had regression coefficient value nearly about unity $\left(\mathrm{b}_{\mathrm{i}}\right.$ * 1$)$ and $\mathrm{S}^{2} \mathrm{~d}_{\mathrm{i}}$ * 0 indicating their stable response over environments with high mean value. Similar results were shown by Patel et al (2014) in which they showed both linear and non- linear components significant and ones with higher general mean, regression coefficient around unity and least deviation from regression were more stable. DBW 97 was found suitable for rich environment and HD 3104 was found suitable for poor environment because of its high genotypic mean for root length, low $b_{i}$ value and sufficient deviation from regression $\left(\mathrm{S}^{2} \mathrm{~d}_{\mathrm{i}} \neq 0\right)$ which was found similar to the results obtained by Sial et al. (2003) who in their study showed environments (E), genotypes $(\mathrm{G}), \mathrm{G} \times \mathrm{E}$ interactions and genotypes $\times$ year interactions were highly significant which sug- gested perceptible seasonal effects. For grain protein, HD 3112 and DBW 97 were found to be stable over the environments because of their high mean, $b_{i} \approx 1$ and $\mathrm{S}^{2} \mathrm{~d}_{\mathrm{i}}$ * 0 across the environments whereas, UP 2825 was found suitable for rich environment and none of the genotypes was found to be suitable for poor environment. El Ameen (2012) showed similar results in which he showed the genotypes performed differently for different yield contributing traits. No single genotype showed stable performance across all environments in case of grain nitrogen yield and wet gluten. GW 445 was recognized as the stable genotype over environments for thousand kernel weight. Harvest index was one such trait in which, all the twelve genotypes exhibited non-significant estimates of linear regression coefficient $\left(b_{i}\right)$ values showing their average stable performance for harvest index across the environments. Najeeb et al. (2004) in their similar study showed $G \times E$ interaction was significant for number of days of heading and effective tillers per plant. Environment (linear) component was significant except for number of effective tillers per plant and grain yield per plant, whereas $G \times E$ (linear) was significant for days to heading and effective tillers per plant. Pooled deviation was significant for most of the traits except 1000-seed weight. Similarly, Banerjee et al. (2006) produced their results by conducting stability analysis for 16 genotypes in which they showed ten genotypes with higher mean values and regression coefficient higher than unity indicated stability under favourable condition. Shah et al. (2009) studied variety-environment interaction, stability and adaptability of various characters and effect of different environments, relationship of characters with grain yield and grain protein percentage for three years. Variety-location, variety-year and variety-location year interactions were highly significant for all characters. Similarly in a study conducted by Banica et al. (2008), lower yield variation at a higher average yield level in the cultivars can be explained by their superior drought resistance which is related to a higher level of osmotic adjustment. In the present study good variability was found for biological yield by genotypes and most stable genotypes across the environments were UP 2825, HD 3112, QLD 39, HD 2932 and DPW 621-50 and good performers under rich environment were HD 2967 and HD 3104. The results were in accordance with the findings of Praveen $e t$ al. (2010) who selected grain weight per tiller and yield contributing traits of wheat showing that only few genotypes showed stability for the characters.

\section{Conclusion}

Our results showed different genotypes showed differential performance with respect to stability for different traits and it was seen that the traits and their stability are not mutually 
exclusive. QLD 11 showed varying performance with respect to stability. HD 3112 exhibited stable performance for spike length, biological yield and grain protein. DBW 97 was found to be stable over the environments for grain protein and spike length. GW 445 was recognized as the stable genotype over environments for spike length and thousand kernel weight. QLD 39 was found to be stable for root length which could be beneficial with respect to nitrogen uptake efficiency. None of the test genotypes showed stability across all environments for grain yield.

\section{ACKNOWLEDGEMENTS}

The experiment was supported by Director Experiment Station, Govind Ballabh Pant University of Agriculture and Technology, Pantnagar.

\section{REFERENCES}

Annichiarico, P. (2002). Genotype $\times$ environment interaction - challenges and opportunities for plant breeding and cultivar recommendations. FAO, Rome. 150pp.

Banerjee, J., Rawat, R.S. and Verma, J.S. (2006). Stability analysis in bread wheat (Tritium aestivum L. em. Thell) and durum wheat (T. durum L.) genotypes. Indian $J$. Genet, 66: 145-146

Banica C, Petcu E, Giura A and Saulescu N. (2008). Relationship between genetic differences in the capacity of osmotic adjustment and other physiological measures of of drought resistance in winter wheat (Triticum aestivum L.). Romanian Agricultural Research, 25: 7-12

Bellidoa, L.L., Rafael, J.L.B. and Redondo, R. (2005). Nitrogen efficiency in wheat under rainfed Mediterranean conditions as affected by split nitrogen application. Field Crops Research, 94: 86-97

Bogard, M., Allard, V., Brancourt-Hulmel, M., Heumez, E., Machet, J.M., Jeuffroy, M.H., Gate, P., Martre, P. and Le Gouis, J. (2010). Deviation from the grain protein concentration grain yield negative relationship is highly correlated to post-anthesis $\mathrm{N}$ uptake in winter wheat. $J$. Exp. Bot., 61: 4303-4312

Eberhart, S.A. and Russell, W.A. (1966). Stability parameters for comparing varieties. Crop Sc., 6:36-40

El Ameen, T. (2012). Stability analysis of selected wheat genotypes under different environment conditions in upper. Egypt. Afr. J. Agric. Res., 7: 4838-4844

Gorny, A.G., Banaszak, Z., Lugowska, B. and Ratajcka, D. (2011). Inheritance of the efficiency of nitrogen uptake and utilisation in winter wheat (Triticum aestivum L.) under diverse nutritional levels. Euphytica., 177: 191 - 206
Jena, S.N., Muduli, K.C. and Tripathy, S. (2005). Genotype $\times$ environment interaction and stability analysis in wheat. Indian-Agriculturist, 49(3): 183-188

King, J., Gay, A., Sylvester-Bradley, R., Bingham, I., Foulkes, J., Gregory, P. and Robinson, D. (2003). Modelling cereal root systems for water and nitrogen capture towards an economic optimum. Ann. Bot., 91: 383-390

Le Gouis, J., Beghin, D., Heumez, E. and Pluchard, P. (2000). Genetic differences for nitrogen uptake and nitrogen utilisation efficiencies in winter wheat. European Journal of Agronomy, 12: 163- 173

Lopez-Bellido, R.J. and Lopez-Bellido, L. (2001). Efficiency of nitrogen in wheat under Mediterranean conditions: Effect of tillage, crop rotation and $\mathrm{N}$ fertilization. Field Crop Research, 71: 31-46

Moll, R.H., Kamprath, E.J. and Jackson, W.A. (1982). Analysis and interpretation of factors which contribute to efficiency of nitrogen utilization. Agronomy J., 74: $562-564$

Najeeb, S., Wani, S.A. and Jeena, A.S. (2004). Stability analysis for yield and its component characters in wheat (Triticum aestivum L.) under cold arid conditions of Ladakh. National J. of Plant Improvement, 6(2): 86-88

Ortiz-Monasterio, Rajaram, S. and McMahon, M. (1997). Genetic progress in wheat yield and nitrogen use efficiency under four N rates. Crop. Sci., 37(3): 898-904

Patel, B.C., Rojasara, Y.M., Akbari, V.R. and Patel, J.A. (2014). Stability analysis for grain yield in bread wheat (Triticum aestivum L.) for irrigated ecosystems. Journal of wheat research, 6(2): 160-162

Praveen, L., Khalil, I.H. and Khalil, S.K. (2010). Stability parameters of tillers grain weight and yield of wheat cultivars in North-West of Pakistan. Pak.J. Bot., 42:1613-1617

Raun, W.R., Solie, J.B., Johnson, G.V., Stone, M.L., Mullen, R.W., Freeman, K.W., Thomason, W.E. and Lukina, E.V. (2002). Improving nitrogen use efficiency in cereal grain production with optical sensing and variable rate application. Agron. J., 94 (4): 815-820

Shah, S.I.H., Sahito, M.A., Tunio, S. and Pirzado, A.J. (2009). Genotype-environment interaction and stability analysis of yield and yield attributes of ten contemporary wheat varieties of Pakistan. Sindh. Univ. Res. J. Sci. Series, 41(1): 13-24

Sial, M.A., Dahot, M.U., Mangrio, S.M., Nisa, Mangan, B., Arain, M.A., Naqvi, M.H. and Shabana, M. (2007). Genotype $\times$ environment interaction for grain yield of wheat genotypes tested under water stress conditions. Sci. Int., 19 (2): 133-137

Witcombe, J.R., Hollington, P.R., Howarth, C.J., Reader, S. and Steele, K.A. (2008). Breeding for abiotic stresses for sustainable agriculture. Phil Trans $R$ Soc Biol., 363:703-716 